\title{
Pengaruh Motivasi Belajar dan Tingkat Kecemasan Terhadap Prestasi Belajar IPA Siswa MTsN. 2 Konawe Selatan
}

\author{
Halmuniati ${ }^{1}$ ), Hasiati ${ }^{2}$ ), La Wui ${ }^{3}$ ), Faizah Binti Awad ${ }^{4}$ ) \\ ${ }^{1}$ ) Dosen Tadris Fisika, Fakultas Tarbiyah dan Ilmu Keguruan (FTIK), Institut Agama Islam Negeri Kendari (IAIN) \\ Kendari; \\ $\left.{ }^{2}\right)$ Mahasiswa Tadris IPA FTIK, IAIN Kendari. \\ ${ }^{3}$ ) Guru Matematika SMK Negeri 1 Mananggu Gorontalo \\ ${ }^{4}$ ) Dosen Fakultas Ushuluddin Adan dan Dakwah Institut Agama Islam Negeri Kendari (IAIN) Kendari; \\ Email Korespondensi : halmuniati88@gmail.com
}

\begin{abstract}
s
This article is a quantitative study with a survey method that aims to find out and describe (1) the effect of learning motivation on science learning achievement; (2) the effect of anxiety level on science learning achievement; and (3) the effect of jointly learning motivation and anxiety levels on the learning achievement of Natural Sciences. This research was conducted at MTs Negeri 2 Konawe Selatan, Southeast Sulawesi, Indonesia. Data collection techniques using questionnaires and documentation. The validity of the instrument uses the Product Moment formula and the reliability of the instrument uses the Cronbach Alpha formula. Data analysis techniques used include the first and second hypothesis testing with simple regression analysis and the third hypothesis test with multiple regression analysis. The results showed that: (1) there was a positive and significant influence between learning motivation on science learning achievement, proved $F_{\text {count }}=6.59$ and $F_{\text {table }}=4.034 ;(2)$ there is a positive and significant influence between the level of anxiety on the learning achievement of science proven $F_{\text {count }}=4.967$ and $F_{\text {table }}=4.034 ;$ (3) there is a positive and significant influence together learning motivation and anxiety level on the learning achievement of science proven $F_{\text {count }}=3.301>F_{\text {table }}=3.187$. The coefficient of determination rsquare $\left(R^{2}\right)$ of 0.088 shows the magnitude of the effective contribution together at $8.8 \%$ and there are still $91.2 \%$ which is influenced by other variables not discussed in this study.
\end{abstract}

Keywords: Learning Motivation, Anxiety Level, Science Learning Achievement.

\begin{abstract}
Abstrak
Artikel ini adalah penelitian kuantitatif dengan metode survei yang bertujuan untuk mengetahui dan mendeskripsikan (1) pengaruh motivasi belajar terhadap prestasi belajar IPA; (2) pengaruh tingkat kecemasan terhadap prestasi belajar IPA; dan (3) pengaruh secara bersama-sama motivasi belajar dan tingkat kecemasan terhadap prestasi belajar IPA. Penelitian ini dilakukan di MTs Negeri 2 Konawe Selatan Sulawesi Tenggara, Indonesia. Teknik pengumpulan data menggunakan kuesioner dan dokumentasi. Validitas instrumen di uji dengan menggunakan Product Moment dan reliabilitas instrumen menggunakan rumus Cronbach Alpha. Teknik analisis data yang digunakan meliputi uji hipotesis pertama dan kedua dengan analisis regresi sederhana dan uji hipotesis ketiga dengan analisis regresi ganda. Hasil penelitian menunjukkan bahwa: (1) terdapat pengaruh yang positif dan signifikan antara motivasi belajar terhadap prestasi belajar IPA dibuktikan $\mathrm{F}_{\text {hitung }}=6,59$ dan $\mathrm{F}_{\text {tabel }}=4,034$; (2) terdapat pengaruh yang positif dan signifikan antara tingkat kecemasan terhadap prestasi belajar IPA dibuktikan $\mathrm{F}_{\text {hitung }}=4,967$ dan $\mathrm{F}_{\text {tabel }}=4,034$; (3) terdapat pengaruh yang positif dan signifikan secara bersama-sama motivasi belajar dan tingkat kecemasan terhadap prestasi belajar IPA dibuktikan $F_{\text {hitung }}=3,301>F_{\text {tabel }}=3,187$. Koefisien determinasi $r_{\text {square }}\left(R^{2}\right)$ sebesar 0,088 menunjukkan besarnya sumbangan efektif secara bersama-sama. Sehingga
\end{abstract}

Kata Kunci: Motivasi Belajar, Tingkat Kecemasan, Prestasi Belajar IPA.

\section{PENDAHULUAN}

Pengembangan pendidikan yang diorentasikan pada segi mutu bukanlah suatu pekerjaan yang mudah, tetapi memerlukan perhatian yang sungguh-sungguh. Pendidikan dikatakan bermutu apabila siswa-siswanya memiliki prestasi belajar yang tinggi. Prestasi belajar siswa merupakan suatu indikator yang digunakan untuk mengukur peningkatan mutu pendidikan di lembaga-lembaga pendidikan. Siswa yang memiliki motivasi yang tinggi, akan memiliki prestasi belajar yang baik pula. Begitu juga sebaliknya, jika siswa memiliki motivasi yang rendah ada kecenderungan akan memiliki prestasi belajar yang rendah pula sehingga motivasi dapat dijadikan tolak ukur seseorang untuk memperoleh prestasi yang akan didapatkan (Nugraha, 2018). Oleh sebab itu, meraih suatu prestasi 
dalam belajar tidaklah mudah, terutama pada pembelajaran Ilmu Pengetahuan Alam (IPA) yang memberikan pengalaman langsung bagi siswa. Prestasi belajar yang tinggi dapat terlaksana apabila siswa memiliki motivasi yang tinggi, baik dari siswa itu sendiri, instrumen sekolah, maupun dari faktor lingkungan sekolah dan tenaga pendidik.

Selain faktor motivasi belajar, salah satu faktor yang menentukan prestasi belajar yang dicapai oleh siswa adalah tingkat kecemasan. Kecemasan merupakan keadaan emosional yang tidak menenangkan seperti perasaan tertekan dalam menghadapi kesulitan sebelum kesulitan itu terjadi dan ditandai dengan adanya perasaan khawatir, prihatin dan rasa takut pada situasi tertentu (Yanti dkk., 2013). Pembelajaran IPA sampai saat ini masih banyak ditemukan kesulitan-kesulitan yang dialami siswa dalam mempelajarinya. Sebagaimana reaksi-reaksi pada umumnya, kecemasan terhadap pembelajaran IPA juga ditujukan oleh gejala psikologis dan fisiologis. Gejala-gejala tersebut dapat muncul pada situasi atau kegiatan belajar yang berkaitan dengan pelajaran IPA. Dimana semakin tinggi tingkat kecemasan belajar siswa maka semakin rendah prestasi belajar yang diperolehnya, begitupun sebaliknya semakin rendah tingkat kecemasan belajar siswa maka semakin tinggi prestasi belajar yang diperolehnya (Rahman, 2015). Kecemasan juga ada yang bersifat membantu (facilitating anxiety) yang dapat meningkatkan performa. Sedikit mengalami kecemasan akan mendorong siswa untuk bertindak (Ormrod, 2012). Oleh sebab itu, kecemasan inilah yang dapat memengaruhi tinggi rendahnya prestasi belajar seseorang.

Motivasi belajar merupakan keseluruhan daya penggerak yang ada dalam diri individu (siswa) yang menimbulkan kegiatan belajar dan memberikan arah kegiatan belajar siswa untuk mencaai tujuan yang dikehendaki oleh siswa yang bersangkutan sebagai subyek belajar (Fathurohman \& Sulistyorini, 2014). Di dalam kegiatan belajar, motivasi merupakan faktor yang sangat penting. Motivasi memberi dorongan yang menggerakkan seseorang untuk melakukan suatu kegiatan. Motivasi merupakan pengarah untuk kegiatan belajar kepada tujuan yang jelas yang diharapkan dapat tercapai (Kiswoyowati, 2011).

Motivasi dapat berfungsi sebagai pendorong usaha dan pencapaian prestasi. dengan adanya motivasi yang baik dalam belajar akan berpengaruh terhadap hasil belajar yang baik, demikian pula apabila siswa memiliki niat belajar yang baik akan terdorong untuk melakukan kegiatan belajar yang maksimal sehingga akan mencapai prestasi yang gemilang (Kompri, 2015).

Ciri-ciri motivasi yang ada pada siswa di antaranya adalah: 1) Tekun menghadapi tugas (dapat bekerja terus-menerus dalam waktu yang lama, tidak pernah berhenti sebelum selesai). 2) Ulet menghadapi kesulitan (tidak lekas putus asa) tidak memerlukan dorongan dari luar untuk berprestasi sebaik mungkin (tidak cepat puas dengan prestasi yang telah dicapainya). 3) Menunjukkan minat terhadap bermacam-macam masalah. 4) Lebih senang bekerja mandiri. 5) Cepat bosan pada tugas yang rutin (hal-hal yang bersifat mekanis, berulang-ulang begitu saja, sehingga kurang efektif). 6) Dapat mempertahankan pendapatnya (kalau sudah yakin akan sesuatu). 7) Tidak mudah melepaskan hal yang diyakini itu. 8) Senang mencari dan memecahkan masalah soal-soal (Sardiman, 2010). Dari pendapat beberapa ahli diatas dapat disimpulkan bahwa motivasi merupakan faktor penting dalam mendorong siswa untuk bisa lebih meningkatkan prestasinya dalam hal pembelajaran.

Kecemasan merupakan perwujudan dari berbagai emosi yang terjadi karena seseorang mengalami tekanan perasaan dan tekanan batin. Kondisi tersebut membutuhkan penyelesaian yang tepat sehingga individu akan merasa aman. Namun, pada kenyataannya tidak semua masalah dapat diselesaikan dengan baik oleh individu bahkan ada yang cenderung di hindari. Situasi ini menimbulkan perasaan yang tidak menyenangkan dalam bentuk perasaan gelisah, takut atau bersalah. Kecemasan bisa bersifat sementara dan berubah-ubah tergantung pada besar kecilnya tekanan yang dihadapi seseorang (Supriyartini, 2010). Pada dasarnya, semua manusia mempunyai perasaan cemas. Dalam taraf rendah kecemasan dapat membuat seseorang lebih terpacu dalam menjalankan sesuatu. Namun jika kecemasannya telah mencapai taraf tidak normal itu akan berakibat buruk pada terganggunya motivasi belajar (Nevid, 2006).

kecemasan belajar merupakan suatu manifestasi emosi yang bercampur baur dan dialami oleh seorang individu sebagai reaksi yang dapat mempengaruhi fisik dan psikis. tingkat kecemasan terdiri dari aspek kognitif, afektif, dan psikomotorik. Pada aspek kognitif dapat diukur dengan indikator: (1) Sulit berkonsentrasi dalam belajar, (2) Dapat berpikir dengan tenang dalam pembelajaran. Pada aspek afektif dapat diukur dengan indikator: (1) Merasa takut ketika menghadapi ujian, (2) Tidak percaya diri dalam menghadapi pelajaran IPA. Pada aspek psikomotorik dapat diukur dengan indikator: (1) Terlihat pucat jika ditunjuk ke papan tulis mengerjakan soal, (2) Sering keringatan jika mengerjakan soal IPA (Herdman, 2015).

Kecemasan dapat diidentifikasikan melalui beberapa gejala yaitu: 1) Secara fisik, yaitu meliputi kegugupan, kegelisahan, tangan dan anggota tubuh yang bergetar, banyak keringat, mulut dan kerongkongan terasa kering, sulit berbicara, sulit bernafas, jantung berdetak kencang, pusing, merasa lemas atau mati rasa, sering buang air kecil dan merasa sensitif atau mudah marah, 2) Secara behavioral meliputi perilaku melekat dan bergantung kepada seseorang, perilaku menghindar dan perilaku terguncang, 3) Secara kognitif meliputi khawatir tentang sesuatu, perasaan terganggu atau ketakutan akan sesuatu yang terjadi di masa depan, keyakinan bahwa sesuatu yang menyeramkan 
akan terjadi tanpa penjelasaan yang jelas, merasa takut akan kehilangan kontrol dan ketidakmampuan menghadapi masalah, memiliki pemikiran bahwa semuanya tidak bisa lagi dikendalikan, merasa sulit memfokuskan pikiran dan berkonsentrasi (Nevid, Jeffrey S, dkk, 2005).

Kecemasan (anxiety) terbagi dari respon perilaku, kognitif, dan afektif, yaitu: 1) Perilaku, berupa gelisah, tremor, berbicara cepat, kurang koordinasi, menghindar, lari dari masalah, waspada, ketegangan fisik, dll. 2) Kognitif, berupa konsentrasi terganggu, kurang perhatian, mudah lupa, kreativitas menurun, produktivitas menurun, bingung, sangat waspada, takut kehilangan kendali, mengalami mumpi buruk, dll. 3) Afektif, berupa tidak sabar, tegang, gelisah, tidak nyaman, gugup, waspada, ketakutan, waspada, kekhawatiran, mati rasa, merassa bersalah, malu, dll (Gail W. Stuart, 2006).

Dari beberapa pendapat diatas tentang kecemasan maka dapat disimpulkan bahwa tingkat kecemasan bisa menjadi masalah yang serius dan akan berpengaruh terhadap kualitas pemahaman siswa tentang mata pelajaran IPA yang berimbas kepada prestasi belajarnya.

Berdasarkan informasi yang didapat pada MTs Negeri 2 Konawe Selatan, diperoleh bahwa sebagaian besar siswa beranggapan bahwa pelajaran IPA adalah pembelajaran yang sangat rumit dan sulit dipahami menyebabkan kebanyakan siswa merasa cemas, khawatir bahkan tertekan dan merasa takut untuk bertanya didalam kelas. Berkaitan dengan motivasi belajar, siswa masih kurang semangat dalam mengikuti pembelajaran IPA, kurang aktif, tidak antusias dan cenderung malas untuk mengerjakan tugas. Sehingga nilai yang diperoleh siswa menjadi tidak maksimal. Penulisan artikel ini bertujuan untuk 1) mengetahui dan mendeskripsikan apakah terdapat pengaruh motivasi belajar terhadap prestasi belajar IPA siswa di MTs Negeri 2 Konawe Selatan; 2) mengetahui dan mendeskripsikan apakah terdapat pengaruh tingkat kecemasan terhadap prestasi belajar IPA siswa di MTs Negeri 2 Konawe Selatan; dan 3) mengetahu dan mendeskripsikan apakah terdapat pengaruh secara bersama-sama motivasi belajar dan tingkat kecemasan terhadap prestasi belajar IPA siswa di MTs Negeri 2 Konawe Selatan.

\section{METODE PENELITIAN}

Penelitian dilakukan dengan pendekatan kuantitatif dengan metode survey. Penelitian ini dilaksanakan MTs. Negeri 2 Konawe Selatan. Populasi dalam penelitian ini yaitu seluruh siswa kelas VIII MTs. Negeri 2 Konawe Selatan tahun ajaran 2018/2019 yang berjumlah 106 siswa dan penentuan sampel menggunakan rumus Slovin dengan nilai kritis $10 \%$ dengan teknik pengambilan sampel menggunakan simple random sampling diperoleh sampel berjumlah 52 siswa. Teknik pengumpulan data menggunakan kuesioner untuk data motivasi belajar dan tingkat kecemasan dan teknik dokumentasi untuk data prestasi belajar IPA. Motivasi belajar dan tingkat kecemasan sebagai variabel independen dan prestasi belajar IPA sebagai variabel dependen. Uji validitas instrumen menggunakan rumus Product Moment dan uji reliabilitas instrumen menggunakan rumus Cronbach Alpha. Teknik analisis data menggunakan statistik deskriptif dan statistik inferensial dengan uji hipotesis pertama dan kedua dengan analisis regresi sederhana dan uji hipotesis ketiga dengan analisis regresi ganda pada taraf signifikansi $5 \%$ atau $\alpha=$ 0,05 ditunjang dengan program Microsoft Office Excel 2007.

\section{HASIL PENELITIAN}

\section{Deskripsi Penelitian}

Data hasil penelitian motivasi belajar dan tingkat kecemasan diukur dengan kuesioner dan prestasi belajar IPA siswa diukur dengan teknik dokumentasi nilai rapor online, diolah dan dianalisis secara deskriptif sebagaimana disajikan pada tabel berikut:

Tabel 1. Data motivasi belajar, tingkat kecemasan dan prestasi belajar

\begin{tabular}{lccc}
\hline \multirow{2}{*}{ Statistik } & \multicolumn{3}{c}{ Data motivasi belajar, tingkat kecemasan dan prestasi belajar IPA } \\
\cline { 2 - 4 } & Motivasi Belajar & Tingkat Kecemasan & Prestasi Belajar IPA \\
\hline Rerata $($ mean $)$ & 78,558 & 76,642 & 76,115 \\
\hline Standar deviasi & 7,607 & 9,714 & 4,545 \\
\hline$X_{\text {Maksimum }}$ & 95 & 91 & 85 \\
\hline$X_{\text {Minimum }}$ & 58 & 51 & 70 \\
\hline
\end{tabular}

Sumber perhitungan menggunakan aplikasi Microsoft office exel 2007

Berdasarkan Tabel 1. Menunjukan bahwa karakteristik analisis data statistik motivasi belajar memiliki rata-rata tertinggi yaitu 78,558, kemudian tingkat kecemasan yaitu 76,642, dan prestasi belajar IPA yaitu 76,115. Untuk standar deviasi, motivasi belajar memperoleh standar deviasi yaitu 7,607, tingkat kecemasan sebesar 9,714, dan prestasi belajar IPA sebesar 4,545. Untuk nilai maksimum, motivasi belajar memperoleh 
sebesar 95, tingkat kecemasan sebesar 91, dan prestasi belajar IPA sebesar 85. Sedangkan nilai minimum, motivasi belajar sebesar 58, tingkat kecemasan sebesar 51, dan prestasi belajar IPA sebesar 70. Hal ini menunjukkan bahwa motivasi belajar memiliki tingkat motivasi pada kategori sangat tinggi, kemudian tingkat kecemasan berada pada kategori tinggi, sedangkan prestasi belajar IPA berada pada kategori sangat rendah.

\section{Uji Persyaratan Analisis} linearitas.

Sebelum pengujian hipotesis, terlebih dahulu dilakukan uji prasyarat analisis, yaitu: uji normalitas dan

a. Pengujian Normalitas

Tabel 2. Hasil Pengujian Normalitas Data

\begin{tabular}{cccc}
\hline Variabel Penelitian & $\mathbf{X}^{2}$ hitung & $\mathbf{X}_{\text {tabel }}$ & Keterangan \\
\hline Motivasi Belajar & $8,299 \mathrm{E}^{+04}$ & 12,592 & Normal \\
\hline Tingkat Kecemasan & $4,858 \mathrm{E}^{+04}$ & 12,592 & Normal \\
\hline Prestasi Belajar & $1,03 \mathrm{E}^{+03}$ & 12,592 & Normal \\
\hline
\end{tabular}

Sumber perhitungan menggunakan aplikasi Microsoft office exel 2007

\section{Kriteria:}

Jika $X^{2}$ hitung $<X^{2}$ tabel artinya berdistribusi normal

Jika $X_{\text {hitung }}^{2}>X_{\text {tabel }}^{2}$ artinya berdistribusi tidak normal

Berdasarkan Tabel 2. Menunjukan pengujian normalitas dengan rumus Chi-kuadrat, pada variabel motivasi belajar diperoleh $X^{2}{ }_{\text {hitung }}=8,299 \mathrm{E}^{+04}$ sedangkan harga $\mathrm{X}_{\text {tabel }}^{2}$ yaitu 12,592. Kemudian tingkat kecemasan diperoleh $\mathrm{X}_{\text {hitung }}^{2}=4,858 \mathrm{E}^{+04}$ sedangkan harga $\mathrm{X}^{2}$ tabel yaitu 12,592 . Sedangkan pada variabel prestasi belajar IPA diperoleh $\mathrm{X}^{2}$ hitung $=1,03 \mathrm{E}^{+03}$ sedangkan harga $\mathrm{X}_{\text {tabel }}^{2}$ yaitu 12,592 . Karena harga $\mathrm{X}^{2}$ hitung lebih kecil dari harga $\mathrm{X}_{\text {tabel }}^{2}$ maka dapat disimpulkan bahwa data variabel motivasi belajar, tingkat kecemasan, dan prestasi belajar berdistribusi normal.

\section{b. Pengujian Linearitas}

Tabel 3. Hasil Pengujian Linearitas Data

\begin{tabular}{cccc}
\hline Korelasi & $\mathbf{F}_{\text {hitung }}$ & $\mathbf{F}_{\text {tabel }}$ & Keterangan \\
\hline $\begin{array}{c}\text { Motivasi belajar terhadap prestasi } \\
\text { belajar }\end{array}$ & $-35558439,62$ & 1,946 & Linear \\
\hline $\begin{array}{c}\text { Tingkat Kecemasan terhadap } \\
\text { prestasi belajar }\end{array}$ & $-3859358,927$ & 1,946 & Linear \\
\hline
\end{tabular}

Sumber dianalisis menggunakan perhitungan manual

Kriteria:

Jika $\mathrm{F}_{\text {hitung }}<\mathrm{F}_{\text {tabel }}$ artinya data linear

Jika $F_{\text {hitung }}>F_{\text {tabel }}$ artinya data tidak linear

Berdasarkan Tabel 3. Menunjukan pengujian linearitas untuk variabel motivasi belajar terhadap prestasi diperoleh $\mathrm{F}_{\text {hitung }}=-35558439,62$ dan $\mathrm{F}_{\text {tabel }}=1,946$. Sedangkan variabel tingkat kecemasan terhadap prestasi belajar diperoleh $\mathrm{F}_{\text {hitung }}=-3859358,927$ dan $\mathrm{F}_{\text {tabel }}=1,946$. Maka dapat disimpulkan bahwa antara variabel $\mathrm{X}_{2}$ (tingkat kecemasan) dan variabel $\mathrm{Y}$ (prestasi belajar) terdapat hubungan linear. Karena harga $\mathrm{F}_{\text {hitung }}$ lebih kecil dari harga $\mathrm{F}_{\text {tabel }}$ maka dapat disimpulkan bahwa data motivasi belajar terhadap prestasi belajar dan tingkat kecemasan terhadap prestasi belajar terdapat hubungan linear.

\section{Pengujian Hipotesis}

a. Pengaruh antara Motivasi Belajar $\left(\mathbf{X}_{1}\right)$ terhadap Prestasi Belajar ( $\left.\mathbf{Y}\right)$

Tabel 4. Hasil Uji Regresi $X_{1}-Y$

\begin{tabular}{cccccc}
\hline Variabel & $\mathbf{F}_{\text {hitung }}$ & $\mathbf{F}_{\text {tabel }}$ & Koef. & Konst. & Keterangan \\
\hline $\mathrm{X}_{1} \rightarrow \mathrm{Y}$ & 6,59 & 4,034 & 0,116 & 60,09 & Terdapat pengaruh signifikan \\
\hline
\end{tabular}

Kriteria:

Jika $\mathrm{F}_{\text {hitung }}<\mathrm{F}_{\text {tabel }}$ artinya $\mathrm{H}_{0}$ diterima

Jika $\mathrm{F}_{\text {hitung }}>\mathrm{F}_{\text {tabel }}$ artinya $\mathrm{H}_{0}$ ditolak 
Berdasarkan tabel 4. Menunjukan bahwa $F_{\text {hitung }}=6,59$ dan $F_{\text {tabel }}=4,034$. Koefisien determinasi $r_{\text {square }}$ sebesar 0,116 yang berarti $11,6 \%$ sumbangan efektif pengaruh motivasi belajar $\left(\mathrm{X}_{1}\right)$ terhadap prestasi belajar $(Y)$. Nilai konstanta adalah 60,09 . Karena harga $F_{\text {hitung }}$ lebih kecil dari harga $F_{\text {tabel }}$ maka dapat disimpulkan bahwa regresi sederhana ini adalah terdapat pengaruh yang positif dan signifikan motivasi belajar terhadap prestasi belajar IPA.

b. Pengaruh antara Tingkat Kecemasan $\left(\mathbf{X}_{2}\right)$ terhadap Prestasi Belajar (Y) Tabel 5. Hasil Uji Regresi $X_{2}-Y$

\begin{tabular}{cccccc}
\hline Variabel & $\mathbf{F}_{\text {hitung }}$ & $\mathbf{F}_{\text {tabel }}$ & Koef. & Konst. & Keterangan \\
\hline $\mathrm{X}_{2} \rightarrow \mathrm{Y}$ & 4,967 & 4,034 & 0,090 & 62,122 & Terdapat pengaruh signifikan \\
\hline
\end{tabular}

Kriteria:

Jika $\mathrm{F}_{\text {hitung }}<\mathrm{F}_{\text {tabel }}$ artinya $\mathrm{H}_{0}$ diterima

Jika $\mathrm{F}_{\text {hitung }}>\mathrm{F}_{\text {tabel }}$ artinya $\mathrm{H}_{0}$ ditolak

Berdasarkan tabel 5. Menunjukan bahwa bahwa $\mathrm{F}_{\text {hitung }}=4,967 \mathrm{dan} \mathrm{F}_{\text {tabel }}=4,034$. Sehingga $\mathrm{F}_{\text {hitung }}>$ $\mathrm{F}_{\text {tabel }}$ atau 4,967 > 4,034. Koefisien determinasi $\mathrm{r}_{\text {square }}$ sebesar 0,090 yang berarti $9 \%$ sumbangan efektif pengaruh tingkat kecemasan $\left(\mathrm{X}_{2}\right)$ terhadap prestasi belajar $(\mathrm{Y})$. Nilai konstanta adalah 62,122. Karena harga $\mathrm{F}_{\text {hitung }}$ lebih kecil dari harga $\mathrm{F}_{\text {tabel }}$ maka dapat disimpulkan bahwa regresi sederhana ini adalah terdapat pengaruh yang positif dan signifikan tingkat kecemasan terhadap prestasi belajar IPA.

c.Pengaruh antara Motivasi Belajar $\left(X_{1}\right)$ dan Tingkat Kecemasan $\left(X_{2}\right)$ secara bersama-sama terhadap Prestasi belajar (Y)

Tabel 6. hasil uji regresi $X_{1}$ bersama $X_{2} \rightarrow Y$

\begin{tabular}{cccccc}
\hline Variabel & $\mathbf{F}_{\text {hitung }}$ & $\mathbf{F}_{\text {tabel }}$ & Koef. & Konst. & Keterangan \\
\hline $\mathrm{X}_{1}$ bersama $\mathrm{X}_{2} \rightarrow \mathrm{Y}$ & 4,967 & 4,034 & 0,090 & 62,122 & Terdapat pengaruh signifikan \\
\hline
\end{tabular}

\section{Kriteria:}

Jika $\mathrm{F}_{\text {hitung }}<\mathrm{F}_{\text {tabel }}$ artinya $\mathrm{H}_{0}$ diterima

Jika $\mathrm{F}_{\text {hitung }}>\mathrm{F}_{\text {tabel }}$ artinya $\mathrm{H}_{0}$ ditolak

Berdasarkan tabel 6. Menunjukan bahwa bahwa $\mathrm{F}_{\text {hitung }}=3,301$ dan $\mathrm{F}_{\text {tabel }}=3,187$. Koefisien determinasi $\mathrm{r}_{\text {square }}$ sebesar 0,088 yang berarti 8,8\% sumbangan efektif pengaruh motivasi belajar $\left(\mathrm{X}_{1}\right)$ dan tingkat kecemasan $\left(\mathrm{X}_{2}\right)$ secara bersama-sama terhadap prestasi belajar $(\mathrm{Y})$. Nilai konstanta adalah 58,465. Karena harga $F_{\text {hitung }}$ lebih kecil dari harga $\mathrm{F}_{\text {tabel }}$ maka dapat disimpulkan bahwa regresi berganda ini adalah terdapat pengaruh yang positif dan signifikan secara bersama-sama motivasi belajar dan tingkat kecemasan terhadap prestasi belajar IPA siswa di MTs Negeri 2 Konawe Selatan.

\section{PEMBAHASAN}

Berdasarkan hasil penelitian yang telah dilakukan pada siswa kelas VIII di MTs Negeri 2 Konawe Selatan, menunjukan bahwa terdapat pengaruh yang positif dan signifikan antara motivasi belajar $\left(\mathrm{X}_{1}\right)$ terhadap prestasi belajar IPA (Y). Motivasi dapat dikatakan sebagai keseluruhan daya penggerak di dalam diri siswa yang menimbulkan kegiatan belajar, sehingga tujuan yang dikehendaki oleh subjek belajar itu dapat tercapai (Sardiman, 2010). Penelitian ini didukung penelitian sebelumnya yang dilakukan oleh Maria Cleopatra yang menyebutkan bahwa terdapat pengaruh motivasi belajar terhadap prestasi (Cleopatra, 2015). Serta penelitian yang di lakukan oleh Ira Nofita Sari dkk., menyebutkan bahwa terdapat pengaruh positif motivasi belajar terhadap prestasi belajar, yang ditunjukkan dengan nilai $F_{\text {hitung }}$ sebesar 11,00 lebih besar dari nilai $F_{\text {tabel }}$ sebesar 3,37 (Sari dkk., 2016). Oleh karena itu, motivasi belajar yang dibangkitkan oleh guru akan memacu siswa untuk mendapatkan prestasi yang lebih baik.

Berdasarkan hasil penelitian yang telah dilakukan menunjukan bahwa terdapat pengaruh yang positif dan signifikan antara tingkat kecemasan $\left(\mathrm{X}_{2}\right)$ terhadap prestasi belajar IPA (Y). Kecemasan merupakan perasaan tidak nyaman dan tidak enak karena ketidaknyamanan atau ketakutan disertai respon otonom (Herdman dan kamitsur, 2015). Salah satu jenis kecemasan yaitu facilitating anxiety atau kecemasan yang membantu, tingkat kecemasan (biasanya relatif rendah) akan meningkatkan performa. Sedikit mengalami kecemasan akan mendorong siswa untuk 
bertindak (Ormrod, 2014). Penelitian ini juga didukung penelitian sebelumnya yang dilakukan oleh Ida Untari yang menyebutkan bahwa terdapat hubungan yang negatif dan signifikan antara tingkat kecemasan terhadap prestasi belajar (Untari, 2014). Serta penelitian yang di lakukan oleh Ani Dwi Lestari dkk., menyebutkan bahwa terdapat pengaruh signifikan tingkat kecemasan terhadap prestasi belajar dengan sumbangan efektif $0,47 \%$ (Lestari dkk., 2012). Oleh karena itu, sedikit mengalami kecemasan akan mendorong siswa untuk memperoleh prestasi yang baik.

Berdasarkan hasil penelitian yang telah dilakukan pada siswa kelas VIII di MTs Negeri 2 Konawe Selatan, menunjukan bahwa terdapat pengaruh yang positif dan signifikan antara motivasi belajar $\left(\mathrm{X}_{1}\right)$ dan tingkat kecemasan $\left(\mathrm{X}_{2}\right)$ secara bersama-sama terhadap prestasi belajar IPA $(\mathrm{Y})$. Faktor-faktor yang mempengaruhi Prestasi belajar seseorang itu dapat digolongkan menjadi dua yaitu dari dalam diri siswa sendiri yang berupa motivasi belajar, sikap, perasaan, dan persepsi. dan faktor dari luar diri siswa yang berupa metode guru dalam mengajar, kurikulum di sekoah, dan media pengajaran (Dimyati dan Mudjiono, 2011). Penelitian ini juga didukung penelitian sebelumnya yang dilakukan oleh Ani Dwi Lestari dkk., terdapat pengaruh signifikan tingkat kecemasan dan motivasi belajar terhadap prestasi belajar dengan sumbangan efektif 13,2\% (Lestari, dkk., 2012). Serta penelitian lain yang di lakukan oleh Mutiatus Solikah menyebutkan bahwa terdapat pengaruh antara kecemasan dan motivasi belajar secara bersama-sama terhadap prestasi belajar dengan koefisien determinannya sebesar 37,3\%. Setelah dilakukan uji signifikan didapat $\mathrm{F}_{\text {hitung }}$ sebesar 8,638 lebih besar dari $\mathrm{F}_{\text {tabel }}$ sebesar 3,328 (Solikah, 2012). Oleh karena itu, dalam kaitannya dengan penelitian ini faktor internal seperti motivasi belajar dan tingkat kecemasan berpengaruh terhadap Prestasi Belajar IPA.

\section{KESIMPULAN}

Berdasarkan data yang diperoleh dari hasil analisis yang dilakukan maka dapat ditarik kesimpulan sebagai berikut: (1) terdapat pengaruh yang positif dan signifikan antara motivasi belajar terhadap prestasi belajar IPA yang ditunjukan dengan koefisien determinasi $r_{\text {square }}$ sebesar 0,116. Setelah dilakukan uji $F$ harga $F_{\text {hitung }}$ sebesar 6,59 dan $F_{\text {tabel }}$ pada taraf signifikansi $5 \%$ sebesar 4,034. Harga $F_{\text {hitung }}$ lebih besar dari $F_{\text {tabel }}(6,59>4,034)$. (2) terdapat pengaruh yang positif dan signifikan antara tingkat kecemasan terhadap prestasi belajar IPA yang ditunjukan dengan koefisien determinasi $r_{\text {square }}$ sebesar 0,090. Setelah dilakukan uji $F$ harga $F_{\text {hitung }}$ sebesar 4,967 dan $F_{\text {tabel }}$ pada taraf signifikansi $5 \%$ sebesar 4,034. Harga $F_{\text {hitung }}$ lebih besar dari $F_{\text {tabel }}(4,967>4,034)$. (3) terdapat pengaruh yang positif dan signifikan antara motivasi belajar dan tingkat kecemasan secara bersama-sama terhadap prestasi belajar IPA yang ditunjukan dengan koefisien determinasi $r_{\text {square }}$ sebesar 0,088. Setelah dilakukan uji $F$ harga $F_{\text {hitung }}$ sebesar 3,301 dan $F_{\text {tabel }}$ pada taraf signifikansi 5\% sebesar 3,187. Harga $F_{\text {hitung }}$ lebih besar dari $F_{\text {tabel }}(3,301>3,187)$. Sehingga berdasarkan hasil penelitian dan kesimpulan tersebut maka peneliti menyarankan agar guru Senantiasa berusaha membangkitkan motivasi belajar siswa pada pembelajaran IPA dengan pendekatan emosional khususnya dalam proses belajar mengajar. Guru hendaknya membawakan pelajaran semenarik mungkin dan gampang dimengerti agar mengurangi kecemasan siswa dalam belajar sehingga prestasi belajar dapat meningkat dengan baik serta sekolah dapat memberikan suasana dan kondisi lingkungan sekolah yang mendukung perkembangan motivasi siswa dan menumbuhkan sikap percaya diri siswa khususnya dalm pembelajaran IPA.

\section{DAFTAR PUSTAKA}

Cleopatra Maria. (2015). Pengaruh Gaya Hidup dan Motivasi Belajar Terhadap Prestasi Belajar Matematika. Jurnal Formatif, Vol. 5, No. 2, 168-181.

Dimyati dan Mudjiono. (2011). Belajar dan Pembelajaran. Jakarta: Asdi Mahastya.

Gail W. Stuart.(2006). Buku Saku Keperawatan Jiwa. Alih Bahasa: Ramona P. Kapoh \& Egi Komara Yudha. Jakarta: EGC.

Herdman, T. H., dan Kamitsuru S. (2015). Diagnosis Keperawatan: Definisi \& Klasifikasi 2015-2017 Edisi 10. Jakarta: EGC.

Kompri. (2015). Motivasi pembelajaran perspektif guru dan siswa. In Konsep Motivasi.

Lestari A. D. dkk. (2015). Pengaruh Tingkat Kecemasan Dan Motivasi Belajar Terhadap Prestasi Belajar Fisika, Jurnal UNDIKSHA, Vol. 2, No. 1. 
Nevid, Jeffrey S, dkk. (2005). Psikologi Abnormal edisi kelimaJilid 1. Jakarta: Erlangga

Nevid, S Jeffrey. (2006). Abnormal Psychology in a Changing World (6 ed.). New Jersey :Prentice Hall.

Nugraha, M. L. (2018). Pengaruh Kecerdasan Numerik Dan Motivasi Belajar Terhadap Prestasi Belajar Matematika Siswa SMK Swasta Jakarta Timur. Jurnal SAP. Vol. 2 No. 3, 262-269.

Ormrod Jeanne Ellis. (2014). Psikologi Pendidikan Membantu Siswa Tumbuh Dan Berkembang Jilid 2. Jakarta: Erlangga.

Rahman Ulfiani. (2015). Pengaruh Kecemasan Dan Kesulitan Belajar Matematika Terhadap Hasil Belajar Matematika Pada Siswa Kelas X MA Negeri 1 Watampone Kabupaten Bone. Jurnal Matematika Dan Pembelajaran ( $M$ A P A N),3(1), 85-102.

Sardiman A. M. (2010). Interaksi dan Motivasi Belajar Mengajar. Jakarta: Rajawali Pres. h. 73.

Sari, I.N. dkk. 2017. Pengaruh Minat Dan Motivasi Belajar Terhadap Prestasi Belajar Fisika Pada Siswa Kelas Xi Ipa Sma Negeri 1 Galing Kabupaten Sambas. JEMS (Jurnal Edukasi Matematika dan Sains), 4 (2), 108114.

Solikah Mutiatus. (2012). Pengaruh Kecemasan Siswa Pada Matematika Dan Motivasi Belajar Terhadap Prestasi Belajar Matematika. Jurnal Unesa, 1(1), 98-105.

Supriyartini. (2010). "Perbedaan Kecemasan dalam Menghadapi Ujian Antara Siswa Program Reguler dengan Program Akselerasi". Sumatera Utara: Universitas Sumatera Utara.

Untari Ida. (2014). Hubungan Antara Kecemasan dengan Prestasi Uji OSCA I pada Mahasiswa Akper PKU Muhammadiyah Surakarta. Jurnal Kebidanan, 6 (1), 10-15.

Yanti, Supri dkk. (2013). Hubungan Antara Kecemasan Dalam Belajar Dengan Motivasi Belajar Siswa. Jurnal Ilmiah Konseling, 2 (1), 283-288. 